\title{
Dbałość o zdrowie - wpływ na zachorowalność i wyniki leczenia nowotworów złośliwych narządów płciowych u kobiet
}

Prof. dr hab. med. KAZIMIERz PityŃsKi

Kierownik Oddziału Klinicznego Ginekologii i Onkologii

Szpitala Uniwersyteckiego w Krakowie,

Wydział Lekarski, Uniwersytet Jagielloński

W potocznym rozumieniu zdrowie to prawidłowy stan organizmu lub brak choroby bądź jej objawów. Światowa Organizacja Zdrowia określa, że zdrowie to nie tylko brak choroby lub niepełnosprawności, lecz także stan dobrego samopoczucia fizycznego, psychicznego i społecznego. Współcześnie zdrowie jest wartością, która pozwala jednostce lub grupie realizować swoje cele i aspiracje. W tak holistycznym ujęciu wyróżnia się kilka wymiarów zdrowia: fizyczne, psychiczne, społeczne i duchowe. W tym kontekście stan zdrowa uwarunkowany jest przez wiele współdziałających ze sobą czynników. W 1974 roku Marc Lalonde, w tym czasie minister zdrowia Kanady, w raporcie dotyczącym nowych perspektyw dla zdrowia Kanadyjczyków przedstawił koncepcję obszarów zdrowia. Punktem wyjścia było zdefiniowanie zdrowia jako stanu wynikającego $\mathrm{z}$ działania 
czynników związanych z dziedziczeniem genetycznym, środowiskiem, stylem życia i opieką medyczną. Jeśli wyjść z takiego założenia, promocja zdrowego stylu życia może wpłynąć na poprawę stanu zdrowia i ograniczyć zapotrzebowanie na opiekę medyczną ${ }^{1}$. Lalonde wyróżnił cztery obszary lub pola zdrowotne, które w decydujący sposób wpływają na stan zdrowia jednostki lub grupy społecznej. Najważniejszą determinantą wśród pól zdrowotnych, wpływającą na zdrowia jest styl życia (53\%), który obejmuje aktywność fizyczną, sposób odżywiania się, umiejętności radzenia sobie ze stresem, stosowanie używek, zachowania seksualne. Dalsze w kolejności są: środowisko fizyczne (21\%) i czynniki biologiczno-genetyczne (16\%). Najmniejszy wpływ na zdrowie, szacowany na ok. 10\%, ma opieka zdrowotna, rozumiana jako zorganizowana struktura, zapewniająca na określonym poziomie dostęp do jakościowo zdefiniowanych świadczeń medycznych. Poza uwarunkowaniami genetycznymi różnorodne czynniki, często współdziałające ze sobą, wpływają na stan organizmu w sposób pośredni i bezpośredni. Spośród czynników pośrednich szczególnie istotne, ze względu na ich wpływ na czynniki bezpośrednie, są warunki makroekonomiczne i społeczno-demograficzne ${ }^{2}$.

Styl życia i zachowania zdrowotne determinują w największym stopniu stan zdrowia człowieka. W obrębie tych pojęć mieści się dbałość o zdrowie i kultywowane zdrowego stylu życia. Odzwierciedleniem takich zachowań w nowo-

${ }^{1}$ M.J. Wysocki, M. Miller, Paradygmat Lalonde'a. Światowa Organizacja Zdrowia i Nowe Zdrowie Publiczne, „Przegląd Epidemiologiczny” (2003) 57, s. 505-512.

2 J. B. Karski, Postępy promocji zdrowia. Przegląd międzynarodowy, Warszawa 2008. 
czesnych społeczeństwach jest między innymi stosowanie się jednostek i całych grup do profilaktyki pierwotnej i profilaktyki wtórnej. Profilaktyka zdrowotna, inaczej prewencja, zapobieganie, w szerokim kontekście dotyczy całej populacji i ma bezpośredni związek z aktualnie obowiązującymi wytycznymi promocji zdrowia. W węższym zakresie obejmuje osoby, których dotyka dany problem zdrowotny, lub osoby w grupie ryzyka jego wystąpienia. Profilaktyka pierwotna skierowana jest do całej populacji lub jej dużej części. Poprzez działania swoiste i nieswoiste ma na celu wyeliminowanie lub zmniejszenie ryzyka rozwoju odpowiednio konkretnej choroby lub wielu rodzajów chorób. Profilaktyka wtórna nakierowana jest na grupę o zwiększonym ryzyku wystąpienia konkretnej choroby. Polega na wykonywaniu odpowiednich badań i testów, przy pomocy których wykrywane są stany poprzedzające chorobę lub symptomy choroby w jej początkowych stadiach.

Zgodnie z najnowszymi danymi Krajowego Rejestru Nowotworów w 2015 roku złośliwe guzy narządu płciowego stanowiły prawie 39\% wszystkich nowotworów złośliwych u kobiet w Polsce (31 701 nowych przypadków) (ryc. 1).

Do nowotworów złośliwych żeńskiego narządu płciowego należy rak piersi. W 2015 roku na ten nowotwór zachorowało 18106 kobiet, co daje 22,2\% wszystkich nowych zachorowań. Oprócz stosowania się do ogólnych zasad zdrowego stylu życia (tab. 1) zwiększenie prozdrowotnej świadomości kobiet pozwala na modyfikowanie, a nawet eliminowanie znanych czynników, które mają związek z większym ryzykiem zachorowania na raka piersi (tab. 2). Dieta eliminująca tłuszcze nasycone, bogata w warzywa i owoce 
(zawierają kwas foliowy) przyczynia się do redukcji ryzyka zachorowania na raka piersi. Podobnie znaczenie ma ograniczanie występowania otyłości, zwłaszcza brzusznej, przede wszystkim po ostatniej w życiu miesiączce. Istotnym czynnikiem ryzyka jest długotrwała ekspozycja gruczołu piersiowego na hormony, głównie estrogeny. Możliwa modyfikacja długości oddziaływania polega na propagowaniu wczesnego macierzyństwa, karmienia piersią i właściwego stosowania substancji zwierających hormony żeńskie ${ }^{3}$.

W zależności od ryzyka zachorowania wyróżniono w populacji kobiet grupę o wysokim i bardzo wysokim ryzyku zachorowania na raka piersi. W tych grupach rak piersi występuje co najmniej czterokrotnie częściej niż w populacji ogólnej. Do grupy bardzo wysokiego (najwyższego) ryzyka, w której prawdopodobieństwo zachorowania wynosi od $25 \%$ do $80 \%$, należą kobiety z potwierdzoną mutacją genów BRCA1 i BRCA2, pochodzące z rodziny obciążonej wystąpieniem trzech lub więcej zachorowań na raka piersi/jajnika wśród krewnych pierwszego i drugiego stopnia, a także $\mathrm{z}$ rozpoznaniem $\mathrm{u}$ krewnych pierwszego stopnia raka synchronicznego lub metachronicznego. Do grupy wysokiego ryzyka (prawdopodobieństwo zachorowania 20-25\%) należą kobiety, których matki lub siostry zachorowały na raka piersi/jajnika przed 40 rokiem życia, mają wśród krewnych pierwszego i/lub drugiego stopnia dwa zachorowania na

${ }^{3}$ K. Szewczyk, Epidemiologia i profilaktyka raka piersi, [w:] Rak piersi, red. J. Kornafel, Warszawa 2011. 
raka piersi i/lub raka jajnika oraz posiadają krewnych pierwszego stopnia z rozpoznanym rakiem metachronicznym ${ }^{4}$.

W ramach profilaktyki pierwotnej u osób z grupy najwyższego ryzyka zachorowania na raka piersi można zastosować selektywne modulatory receptora estrogenowego, np. tamoksifen lub raloksifen. Ustalono, że tamoksifen stosowany w chemoprewencji raka piersi ma w grupie kobiet z genetycznie uwarunkowanym ryzykiem rozwoju raka piersi skuteczność podobną do profilaktycznego usunięcia przydatków. Nie chroni jednak przed wystąpieniem raka jajnika, a dodatkowo kilkukrotnie zwiększa ryzyko zachorowania na raka błony śluzowej trzonu macicy. Wspomniana profilaktyczna adneksektomia, przeprowadzona u kobiet z najwyższym ryzykiem zachorowania na raka piersi pomiędzy 3540 rokiem życia, redukuje to ryzyko o $60-75 \%$. W bardzo istotny sposób zabieg ten zmniejsza ryzyko zachorowania na raka jajnika. Metodą wzbudzającą znaczne kontrowersji, zaliczaną także do profilaktyki pierwotnej, jest profilaktyczna mastektomia, która u kobiet z mutacją genów BRCA1/ BRCA2 zmniejsza ryzyko zachorowania o $90 \%$.

Przed zastosowaniem chemoprewencji lub profilaktycznej chirurgii kobiety powinny podlegać ścisłej kontroli zgodnie ze schematem zawartym w tabeli 3. Samobadanie piersi jest często określane jako nieinwazyjny test przesiewowy. Mimo wielu ograniczeń zachęcanie i nauczanie samobadania skłania kobiety do myślenia o własnym zdrowiu.

${ }^{4}$ J. Jassem i in., Rak piersi. Zalecenia postępowania diagnostyczno-terapeutycznego w nowotworach złośliwych, www.onkologia.zalecenia.med. pl na 2009 rok. 
Stwierdzenie niepokojących symptomów powinno skutkować natychmiastową konsultacją lekarską (tab. 4).

Kryteria metody przesiewowej dla raka piersi aktualnie spełnia jedynie mammografia. W Polsce w ramach Populacyjnego Programu Wczesnego Wykrywania Raka Piersi bezpłatne badanie mammograficzne obejmuje kobiety w wieku 50-69 lat. Ultrasonografia piersi nie jest metodą alternatywną w stosunku do mammografii, natomiast jest jej cennym uzupełnieniem w procesie diagnostycznym, zwłaszcza u kobiet młodszych, z gęstą gruczołową budową piersi.

Rak szyjki macicy należy do nowotworów o najlepiej poznanej etiologii. Czynnikiem wywołującym raka szyjki macicy jest przewlekła infekcja wirusem brodawczaka ludzkiego o wysokim potencjale onkogennym (przede wszystkim typ 16 i 18). Spośród 150 typów HPV 40 infekuje żeńskie narządy płciowe. Szczyt zakażeń występuje pomiędzy 20 a 25 rokiem życia. Zakażeniu towarzyszy w wielu przypadkach dodatkowy czynnik sprzyjający, zwany kofaktorem, np. palenie papierosów, duża liczba porodów (powyżej siedmiu), długotrwała antykoncepcja hormonalna, inne zakażenia przenoszone drogą płciową, m.in. zakażenie wirusem opryszczki, HIV, Chlamydia trachomatis, przewlekłe stany zapalne, niedobory odporności, niedobór antyoksydantów w diecie (tab. 5, tab. 6).

W Polsce zachorowalność na raka szyjki ma tendencję spadkową. Niestety wyniki leczenia tego nowotworu w naszym kraju są nadal gorsze niż w większości krajów Europy. Proces rozwoju raka szyjki macicy trwa przez wiele lat, a jego wystąpienie poprzedzają tzw. stany przedrakowe. Kliniczne 
do stanów przednowotworowych szyjki macicy zalicza się rogowacenie przerostowe (leukoplakia), brodawczaka płaskonabłonkowego i polipy gruczołowe. Histologicznie stanem przedrakowym jest dysplazja nabłonka szyjki macicy o różnym stopniu nasilenia, która nieleczona prowadzi do wystąpienia raka. Stany przedrakowe i wczesny rak szyjki macicy zazwyczaj nie dają charakterystycznych objawów. Mogą im towarzyszyć upławy, nieprawidłowe krwawienia z dróg rodnych, krwawienia kontaktowe. Przedinwazyjny rak szyjki macicy najczęściej stwierdzany u kobiet pomiędzy 30 a 40 rokiem życia, rak inwazyjny pomiędzy 40 a 60 rokiem życia.

Jak wynika $z$ analizy czynników ryzyka zachorowania na raka szyjki macicy, zmniejszenie ryzyka zachorowania na ten nowotwór jest możliwe poprzez zmianę zachowań seksualnych, zaprzestanie palenia papierosów, właściwą dietę bogatą w antyoksydanty. Innym sposobem profilaktyki pierwotnej raka szyjki macicy jest szczepienie przeciw wirusowi brodawczaka ludzkiego. Pierwsze szczepionki pojawiły się na rynku przed 12 laty. Aktualnie na polskim rynku dostępne są szczepionki dwu-, cztero-i dziewięciowalentne. Wszystkie szczepionki przeciwko HPV zapewniają ochronę przed HPV typu 16 i 18, które odpowiadają za około 66\% zachorowań na raka szyjki macicy i większość innych zachorowań na raka związanego z zakażeniem HPV. Szczepionka dziewięciowalentna (HPV-9) dodatkowo obejmuje pięć typów onkogennych, które są przyczyną około $15 \%$ przypadków raka szyjki macicy. Szczepionki czterowalentna i dziewięciowalentna (HPV-4 i HPV-9) chronią również przed 
HPV typu 6 i 11, które wywołują brodawki zewnętrznych narządów płciowych i odbytu.

Zgodnie z obowiązującym zaleceniami Advisory Committee on Immunization Practices (ACIP) rutynowe szczepienia przeciwko HPV należy rozpocząć w wieku 1112 lat. Pierwszą dawkę można podać po ukończeniu 9 roku życia. Szczepienie zaleca się również nieszczepionym wcześniej osobom w wieku 13-26 lat (płeć żeńska) oraz 13-21 lat (płeć męska), a także pacjentom, którzy nie otrzymali pełnego, trzydawkowego schematu szczepienia. Można również szczepić mężczyzn w wieku 22-26 lat. Zaleca się, aby u dziewcząt i kobiet stosować preparat HPV-2, HPV-4 (dopóki szczepionka będzie dostępna) lub HPV-9, natomiast u mężczyzn - HPV-4 (dopóki szczepionka będzie dostępna) lub HPV-9. Wyniki przeprowadzonych badań wskazują na wysoki stopień ochrony przed infekcją HPV 16 i $18^{5}$. Pomimo to kobiety zaszczepione, ze względu na nieznaną dotychczas długość ochronnego działania szczepionki, powinny nadal uczestniczyć w skriningu raka szyjki macicy.

Aktualnie najbardziej efektywną metodą wykrywania stanów przednowotworowych na szyjce macicy i wczesnych stadiów tego nowotworu jest cytologia. Na tym badaniu opiera się, zapoczątkowany w Polsce w 2006 roku, Program Profilaktyki Raka Szyjki Macicy. Program polega na wykonywaniu co trzy lata bezpłatnej cytologii wśród kobiet w wieku 25-59 lat. W przypadku nieprawidłowego wyniku badania cytologicznego pacjentka kierowana jest do diagnostyki po-

${ }^{5} \mathrm{M}$. Lehtinen i in., Ten-year follow-up of human papillomavirus vaccine efficacy against the most stringent cervical neoplasia end-point. Registrybased follow-up of three cohorts from randomized trials, „BMJ Open” (2017) 7(8), nr art. e015867. 
szerzonej, w ramach której przeprowadza się kolposkopię i jeżeli istnieją wskazania, wycinki z szyjki macicy oddaje się do oceny histopatologicznej. Z aktualnych statystyk wynika, że w Programie Profilaktycznym Raka Szyjki Macicy uczestniczy $21 \%$ uprawnionych kobiet, a kolejne $25 \%$ wykonuje cytologię ambulatoryjnie, co nie jest rejestrowane. Oprócz tego $29 \%$ kobiet bada się prywatnie. W sumie badaniami cytologicznymi objętych jest w naszym kraju 75\% kobiet. Szacuje się, że efektem działania Programu Profilaktycznego w populacji kobiet pomiędzy 25 a 59 rokiem życia jest roczny spadek zachorowalności i umieralności na raka szyjki macicy odpowiednio o $6,1 \%$ i $4,7 \%$.

Nowotworem ginekologicznym, będącym największym wyzwaniem dla współczesnej ginekologii onkologicznej, jest rak jajnika. Najbardziej aktualne badania pokazują heterogenne pochodzenia raka jajnika, z czego wynika, że nie jest to pojedyncza jednostka chorobowa. Różne pochodzenie i odmienna biologia utrudniają opracowanie skutecznych metod wczesnego wykrywania. Lokalizacja jajnika w miednicy mniejszej znacznie utrudnia z kolei rozpoznanie zmian patologicznych w jajnikach we wczesnym stadium i przyczynia się do maskowania objawów. Stad większość raków jajnika wykrywana jest w zaawansowanych stadiach, co przekłada się na niską wyleczalność, mimo znacznych postępów, jakie poczyniła współczesna onkologia.

Wyróżnia się różne typy histologiczne tego nowotworu. Najczęstszy jest rak surowiczy (70\% przypadków raka jajnika), który prawie w 90\% ma postać niskozróżnicowaną, o szybkim rozwoju i przebiegu oraz złym rokowaniu. Najważniejszym z czynników ryzyka zachorowania na raka 
jajnika jest predyspozycja genetyczna (tab. 7). Postać rodzinna lub dziedziczna stanowi 15-24\% przypadków raka jajnika, w tym większość (10-18\%) jest związana z mutacjami w genach BRCA1 lub BRCA2. Rodzinna historia raka piersi i jajnika nie zawsze wiąże się z obecnością mutacji w genach supresorowych BRCA1/2. W dużej części tych rodzin nie udaje się ustalić podłoża genetycznego.

Ryzyko rozwoju raka jajnika jest zależne od liczby przebytych cykli owulacyjnych oraz tempa wzrostu i rozwoju w okresie płodowym i dzieciństwie. Wyższa zachorowalność na ten nowotwór w krajach o wysokim statusie socjoekonomicznym spowodowana jest mniejszą dzietnością, krótszym okresem karmienia piersią i częstszym niż w krajach biednych stosowaniem technik wspomaganego rozrodu.

Innym czynnikiem ryzyka, ale o mniejszym znaczeniu niż powyższe, jest otyłość wyrażona współczynnikiem BMI. $Z$ kolei rolę protekcyjną, chroniąca przed zachorowaniem na raka jajnika ma duża liczba przebytych ciąż, długie okresy karmienia piersią i długotrwałe stosowanie antykoncepcji hormonalnej $j^{6}$. Natomiast hormonalna terapia zastępcza zastosowana w okresie pomenopauzalnym zwiększa ryzyko zachorowania na raka endometrioidalnego i raka jasnokomórkowego jajnika ${ }^{7}$.

Wczesne wykrycie raka jajnika jest najczęściej przypadkowe. Na wczesnym etapie rozwoju nowotworu objawy nie występują lub są niespecyficzne (tab. 8). Te niecharakterystyczne symptomy określane są maską brzuszną raka jajni-

${ }^{6}$ C.A. Demetriou i in., Methylome analysis and epigenetic changes associated with menarcheal age, „PLoS One” (2013) 8, nr art. e79391.

${ }^{7}$ D.M. Purdie i in., Hormone replacement therapy and risk of epithelial ovarian cancer, „British Journal of Cancer” (1999) 81, s. 559-563. 
ka. Jak do tej pory nie powiodły się próby opracowania metod wczesnego wykrywania raka jajnika. Aktualnie istniejące techniki obrazowe i znane markery nowotworowe, nawet stosowane łącznie, mają zbyt niską czułość i swoistość, aby znaleźć zastosowanie w skriningu tego nowotworu. Przyczyny zachorowania nie są jednoznacznie zdefiniowane i często takie same jak dla wielu innych chorób. Część z nich wynikająca ze stylu życia, np. otyłość, palenie tytoniu i dieta bogatotłuszczowa, jest możliwa do modyfikacji. Niemożliwe lub trudne do zmiany są: wiek przy pierwszej i ostatniej miesiączce, wysoki wzrost, niska rodność i niekarmienie piersią. Ponadto wątpliwe jest zalecanie w populacji ogólnej długotrwałego stosowania antykoncepcji hormonalnej, podwiązywania jajowodów czy usuwania macicy tylko w celu profilaktyki pierwotnej raka jajnika.

Chirurgię prewencyjną w postaci profilaktycznej adneksektomii można zaproponować nosicielkom mutacji genów BRCA1/2, po zakończeniu planów prokreacyjnych, w wieku 35-40 lat. Zgodnie z dzisiejszą wiedzą identyfikacja tych kobiet nie powinna obejmować tylko tych $z$ wywiadem rodzinnym, ale także szerszą grupę wszystkich chorych z rakiem jajnika. Wartość wywiadu rodzinnego w typowaniu do badań genetycznych okazała się bowiem ograniczona. Nowoczesne metody molekularne umożliwiają poszerzenie zakresu identyfikacji mutacji. Usunięcie przydatków zmniejsza ryzyko rozwoju raka jajnika, jajowodu i otrzewnej do ok. 5\%. Trwają badania, w których rezultacie może się okazać, że w profilaktyce niskozróżnicowanego, surowiczego raka jajnika u nosicielek mutacji BRCA1/2 wystarczające jest 
usunięcie tylko jajowodów, bez pozbawiania kobiety funkcji hormonalnej jajnika ${ }^{8}$.

Rak błony śluzowej trzonu macicy jest drugim po raku piersi najczęstszym nowotworem żeńskiego narządu płciowego. Zachorowalność ma stałą tendencję wzrostową, co wynika przede wszystkim z wydłużania się życia kobiet. Z danych Głównego Urzędu Statystycznego za 2016 rok wynika, że mężczyźni w Polsce żyli przeciętnie 73,9 lat, natomiast kobiety 81,9 lat. W porównaniu z 1990 rokiem żyjemy dłużej odpowiednio o 7,7 i 6,7 lat. W ciągu ostatnich trzech dekad liczba nowych zachorowań na ten nowotwór zwiększyła się prawie dwukrotnie.

Oprócz wieku do zachorowania na raka endometrium predysponują: późna menopauza, otyłość, cukrzyca, nadciśnienie, brak ciąży i porodu, przebyte leczenie niepłodności, zaburzenia hormonalne, przyjmowanie tamoksifenu. Paradoksalnie palenie tytoniu zmniejsza prawdopodobieństwo zachorowania na ten nowotwór, podobnie jak używanie antykoncepcji hormonalnej.

Rak endometrium jest drugim najczęściej występującym nowotworem związanym z zespołem Lyncha. Zespół Lyncha (dawniej określany jako HNPCC) jest dziedziczony w sposób autosomalny dominujący. Za rozwój zespołu odpowiada obecność mutacji jednego z genów naprawczych grupy mismatch repair (MMR). Kobiety z zespołem Lyncha mają w ciągu życia 30-70\% ryzyka zachorowania na raka endometrium.

${ }^{8}$ B.K. Erickson, M.G. Conner, C.N. Landen Jr., The role of the fallopian tube in the origin of ovarian cancer, "American Journal of Obstetrics Gynecology" (2013) 209, s. 409-414. 
Rak endometrium rozwija się zazwyczaj powoli, z reguły na bazie nieprawidłowych rozrostów błony śluzowej macicy, i objawia się wcześnie, wywołując nieprawidłowe krwawienia z dróg rodnych. Taki przebieg powoduje, że większość przypadków raka endometrium diagnozowana jest w pierwszym stopniu zaawansowania, co przekłada się na wysoki odsetek całkowitych wyleczeń.

Do tej pory nie opracowano żadnej skutecznej metody wczesnego wykrywania raka błony śluzowej trzonu macicy, a profilaktyka pierwotna ogranicza się do dbania o właściwą masę ciała, prawidłowe leczenie cukrzycy i nadciśnienia oraz wyrównanie zaburzeń hormonalnych. U kobiet z zespołem Lyncha, które ukończyły 40 lat oraz nie mają planów prokreacyjnych, należy rozważyć wycięcie macicy oraz obustronne usunięcie jajników. Takie postępowanie ma charakter profilaktyki pierwotnej i w znacznym stopniu zapobiega rozwojowi raka endometrium i raka jajnika.

Najskuteczniejszą metodą profilaktyki tego nowotworu w ogólnej populacji kobiet jest regularne poddawanie się badaniu ginekologicznemu, połączonemu z ultrasonograficznym obrazowaniem narządu rodnego.

Chorzy z nowotworami rozpoznanymi we wcześniejszych stopniach zaawansowania mają istotnie większe szanse na pełne wyleczenie. Warunkiem koniecznym do wykrycia choroby na tym etapie jest zachowanie tzw. „czujności onkologicznej”, która powinna obowiązywać zarów- 
no społeczeństwo, jak i lekarzy. Dla pacjentów oznacza to znajomość podstawowych objawów choroby nowotworowej i natychmiastowe zgłaszanie się do lekarza w wypadku wystąpienia niepokojących symptomów. Czujność onkologiczna w odniesieniu do lekarza polega na aktywnym poszukiwaniem objawów choroby nowotworowej u zgłaszającego się pacjenta, z angażowaniem wszelkich dostępnych metod diagnostyki onkologicznej.

Nie mniej istotnym narzędziem prowadzącym do poprawy wyników leczenia jest profilaktyka zdrowotna rozumiana jako działanie zmierzające do zapobiegania wystąpienia choroby, jej wczesne wykrycie i leczenie. Obejmuje ona utrwalanie prawidłowych wzorców zdrowego stylu życia, zapobieganie chorobom poprzez kontrolowanie czynników ryzyka i wczesne wykrywanie oraz leczenie choroby poprzez uczestnictwo w zorganizowanych badaniach przesiewowych.

Tabela 1. Zasady zdrowego stylu życia

I. Zdrowe, racjonalne odżywianie

II. Odpowiednia aktywność fizyczna

III. Umiejętność radzenia sobie ze stresem

IV. Odpowiednia ilość godzin snu i wypoczynku

V. Życie bez szkodliwych uzależnień od nikotyny, alkoholu, narkotyków, leków, innych substancji

VI. Utrzymywanie prawidłowej masy ciała 
Rycina 1. Zachorowania na nowotwory złośliwe u kobiet, 2015 (http://onkologia.org.pl/raporty/\#wykres_kolowy)

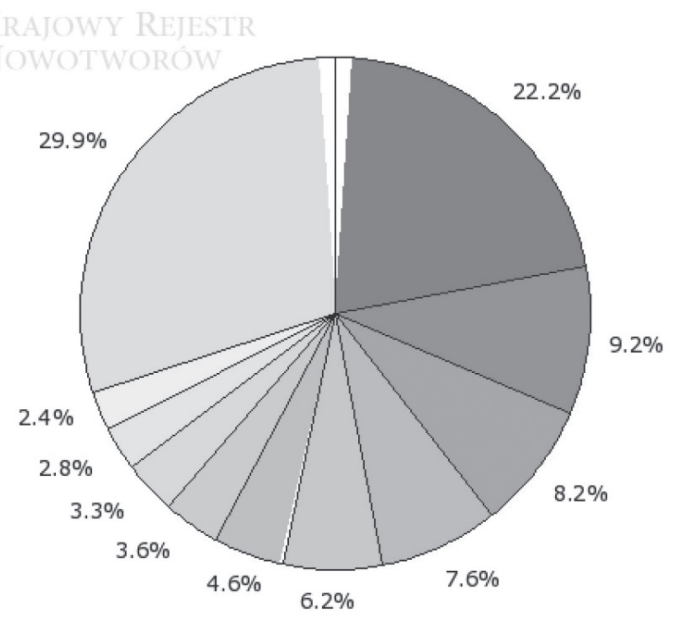

Nowotwór złośliwy sutka Nowotwór złośliwy oskrzela i płuca Inne nowotwory złośliwe skóry Nowotwór złośliwy trzonu macicy

Nowotwór złośliwy jelita grubego

Nowotwór złośliwy jajnika

Nowotwór złośliwy tarczycy

Nowotwór złośliwy szyjki macicy

Nowotwór złośliwy odbytnicy

Nowotwór złośliwy żołądka

Inne 
Tabela 2. Czynniki ryzyka zachorowania na raka piersi

\section{Czynniki ryzyka zachorowania na raka piersi}

- Wiek

- Czynniki dziedziczne.

- Czynniki środowiskowe

- Rasa

- Gęstość piersi - „gęsta”

- Wiek pierwszej i ostatniej miesiączki

- Napromienienie piersi w przeszłości
- Brak potomstwa lub późny wiek urodzenia pierwszego dziecka -

- Tabletki antykoncepcyjne

- Hormonalna terapia zastępcza

- Karmienie piersią

- Alkohol

- Nadwaga lub otyłość

- Brak ćwiczeń fizycznych

- Praca w nocy

Tabela 3. Badania zalecane u osób z grup wysokiego ryzyka zachorowania na raka piersi/jajnika

- samobadanie piersi co miesiąc

- badanie lekarskie co pół roku od 25. roku życia

- ultrasonografia piersi co 6 miesięcy od 25. roku życia

- mammografia co rok od 35. roku życia

- badanie ginekologiczne co pół roku

- ultrasonografia przezpochwowa co rok od 30. roku życia

- oznaczanie antygenu Ca 125 co rok od 35. roku życia

- przeciwwskazana antykoncepcja hormonalna

- względnie przeciwwskazana hormonalna terapia zastępcza

- okresowa kontrola w poradni genetycznej 
Tabela 4. Objawy sugerujące raka piersi

\section{Objawy sugerujące raka piersi}

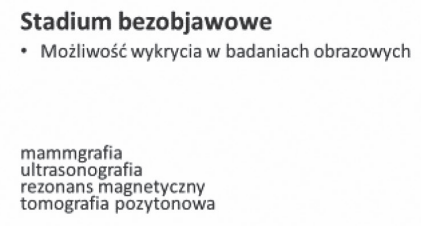

Stadium objawowe

- Guz

- Ból bez uchwytnej przycyzny

- Wyciek z brodawki sutkowej

- Asymetria sutków

- Weiągnięcie brodawki

- Owrzodzenie brodawki lub skóry piersi

- Niewielkiego stopnia pogrubienie skóry

- Obraz skórki pomarańczy (nacieczone więzadła)

- Świąd lub pieczenie brodawki.

- Powiększenie regionalnych węzłów chłonnych

- Zapalenie

Tabela 5. Czynniki ryzyka zachowania na raka szyki macicy (główne)

- wiek

- infekcje HPV (głównie typ 16 - widoczny w 53\% raka inwazyjnego i H-SIL) oraz HSV-2 (opryszczki)

- wczesne rozpoczęcie życia seksualnego (< 17 r.ż.)

- duża liczba partnerów seksualnych

- nieużywanie prezerwatyw podczas stosunku

- duża liczba porodów

- niski status socjoekonomiczny

- palenie tytoniu

- czynnik „męski” - partnerzy niemonogamiczni, z infekcją HPV

- stwierdzona wcześniej patologia w badaniu cytologicznym 
Tabela 6. Czynniki ryzyka zachowania na raka szyki macicy (prawdopodobne)

- wieloletnie stosowanie hormonalnych środków antykoncepcyjnych

- niewłaściwa dieta, uboga w witaminy C i A

- zakażenie wirusem HIV

- $\quad$ stany zapalne narządu płciowego przenoszone drogą płciową, inne niż HPV (np. chlamydia, rzęsistek, wirus opryszczki HSV-2)

- stany obniżonej odporności - zakażenie wirusem HIV, immunosupresja w związku z przeszczepieniem narządu

Tabela 7. Czynniki ryzyka zachorowania na raka jajnika (główne) wiek

- nosicielstwo mutacji genów BRCA1 i BRCA2

- zespół dziedzicznego raka piersi i raka jajnika

- zespół dziedzicznego raka jajnika

- rodzinne występowanie dziedzicznego niepolipowatego raka jelita grubego

- bezdzietność

- nieskuteczna stymulacja owulacji

- otyłość 
Tabela 8. Objawy raka jajnika

\begin{tabular}{|c|l|}
\hline \multicolumn{1}{|c|}{ Wczesne } & \multicolumn{1}{|c|}{ Późne } \\
\hline Niespecyficzne: & powiększanie się obwodu \\
wzdęcia, niestrawność, & brzucha, wodobrzusze, \\
odbijanie, czkawka, uczucie & utrata masy ciała, \\
pełności w jamie brzusznej, & wyniszczenie, bóle brzucha, \\
zaparcia & wykrywalny w badaniu duży \\
W badaniu ginekologicznym: & opór w miednicy lub w jamie \\
powiększony jajnik, mała & brzusznej \\
ruchomość jajników, mała & \\
bolesność lub niewrażliwość \\
na badanie, powiększanie się \\
masy guza w krótkim czasie \\
obserwacji
\end{tabular}

Modlitwa - Zdrowie - Komunikacja

Praca i życie sióstr felicjanek

red. ks. Robert Nęcek, ks. Wojciech Misztal, Kraków 2019, s. 105-123

DOI: http.doi.org/10.15633/9788374387651.07 
